\title{
Percepatan Pembangunan di Empat Daerah Tertinggal di Jawa Timur: Perspektif Feminis
}

\section{Mita Yesyca}

Universitas Kristen Indonesia

\begin{abstract}
Abstrak: Di tingkat global, nasional dan daerah, perempuan dipandang sebagai agen pembangunan. Ibarat 'sekali mendayung, dua-tiga pulau terlampaui,' program pemberdayaan ekonomi perempuan khususnya di pedesaan atau daerah-daerah tertinggal diyakini mampu membawa dampak positif terhadap perempuan itu sendiri, keluarga atau rumah tangganya, perekonomian daerah setempat hingga perekonomian nasional. Studi pustaka ini hendak meninjau kembali keyakinan tersebut. Dengan menunjukkan interaksi antara gender dan ketimpangan ekonomi dalam hidup laki-laki dan perempuan di daerah-daerah tertinggal, khususnya di Jawa Timur, simpulan dari tulisan ini adalah bahwa program-program yang menitikberatkan pada pelibatan perempuan pedesaan agar dapat membuka akses mereka terhadap pasar belum tentu memberdayakan perempuan pedesaan dalam artian mentransformasi posisi mereka yang timpang terhadap keutamaan laki-laki dalam ekonomi. Pemberdayaan yang transformatif inilah yang sudah seharusnya tetap menjadi agenda pembangunan daerah-sensitif gender.
\end{abstract}

Kata Kunci: Perempuan, Daerah Tertinggal, Jawa Timur, Pembangunan, Pemberdayaan

Abstract: At the global, national and local levels, women are seen as the development agent. It's like 'once rowing, two or three islands are passed,' women's economic empowerment programs, especially in rural or underdeveloped areas are believed to be able to bring positive impact on women themselves, their families or households, local economies and national economies. This literature study wants to take a further look at the notion. By showing the interaction between gender and economic inequality in men and women's lives in underdeveloped areas, especially in East Java, the conclusion of this paper is that programs that focus on rural women's involvement in order to enable their access to the markets are not necessarily empowering women in the sense of transforming their unequal position against men's preeminence in the economy. Such transformative empowerment should become an agenda for local development-a gender sensitive one.

Key Words: Women, Underdeveloped Area, East Java, Development, Empowerment

Korespondensi Penulis:

Mita Yesyca, Program Studi Hubungan Internasional, Universitas Kristen Indonesia

Jl. Mayjen Sutoyo No. 2, Cawang, Jakarta Timur.

E-mail: mita.yesyca@uki.ac.id 


\section{PENDAHULUAN}

Penelitian ini merupakan studi pustaka mengenai kebijakan-kebijakan percepatan pembangunan yang menitikberatkan peran perempuan sebagai kunci pengentasan kemiskinan di Indonesia. Dasar dari kebijakan ini, misalnya, tercermin dalam pernyataan Menteri Pemberdayaan Perempuan dan Perlindungan Anak Yohana Susana Yembise bahwa perempuan Indonesia berkontribusi penting bagi ekonomi Indonesia dan pengentasan kemiskinan, dan karenanya perlu didukung dengan pemberian akses yang memadai dalam hal pendidikan, kebebasan bekerja, dan pendapatan mandiri (Elsynosa 2018). Hal serupa dinyatakan oleh Menteri Badan Perencanaan Pembangunan Nasional (Bappenas) Bambang Broedjonegoro bahwa tingkat partisipasi angkatan kerja perempuan Indonesia sebesar 51\%, lebih rendah dari laki-laki yang sebesar $82 \%$. Sementara, tingginya partisipasi angkatan kerja perempuan menjadi faktor yang memengaruhi kemajuan sebuah negara. Karenanya Menteri Bambang mengupayakan kesetaraan gender dalam akses dan kondisi kerja di Indonesia (Arta 2018).

Di tingkat global, pemikiran ini dapat ditelusuri awal mulanya ketika isu perempuan dan kemiskinan menjadi agenda utama pembangunan internasional dalam Konferensi Dunia tentang Perempuan yang keempat di Beijing tahun 1995. Sejak saat itu, perempuan sering disebut sebagai aktor penting dalam pengentasan kemiskinan dan tidak luput dalam agenda pembangunan internasional hingga hari ini (Lagarde 2016, Diop 2015). Sedangkan di tingkat daerah, perhatian kepada ekonomi perempuan sudah ada sejak pemerintahan Presiden B. J. Habibie melalui pemberian hibah bergulir untuk Simpan Pinjam Kelompok Perempuan (SPP). SPP merupakan pemberian modal untuk kelompok perempuan yang mempunyai kegiatan simpan pinjam. Di bawah 
Program Nasional Pemberdayaan Masyarakat (PNPM) Mandiri selama 2007-2014, SPP dilanjutkan di masa kepemimpinan Presiden Susilo Bambang Yudhoyono. Di era Presiden Joko Widodo, meski PNPM Mandiri telah berakhir pada 31 Desember 2014, dana bergulir tersebut tetap dapat dikelola oleh Badan Kerja Sama Antardesa (BKAD), dilaksanakan oleh Unit Pengelola Kegiatan (UPK) dan diputuskan bersama melalui Musyawarah Antardesa (MAD).

Di bawah pemerintahan Presiden Joko Widodo pula, daerah tertinggal mendapat perhatian besar dari pemerintah. Empat daerah di Provinsi Jawa Timur, yakni Kabupaten Bondowoso, Kabupaten Situbondo, Kabupaten Bangkalan, dan Kabupaten Sampang masuk ke dalam 122 daerah tertinggal tahun 2015-2019 yang ditetapkan melalui Peraturan Presiden Nomor 131 Tahun 2015 (Lumanauw 2015). Kementerian Desa, Pembangunan Daerah Tertinggal (PDT) dan Transmigrasi, merespon keluarnya Perpres Nomor 131 Tahun 2015 dengan menargetkan pengentasan daerah tertinggal pada Rencana Pembangunan Jarak Menengah Nasional (RPJMN) 2015-2019 sebanyak 80 kabupaten dari total 122 kabupaten yang tertinggal. Target itu berusaha dicapai lewat berbagai program, dengan fokus tiga hal: sarana dan prasarana, pengembangan sumber daya manusia dan pertumbuhan ekonomi.

Sekretaris Direktorat Jenderal Pembangunan Daerah Tertinggal RI Razali menyebutkan bahwa aspek sarana dan prasarana diejawantahkan melalui pembangunan jalan, pasar, listrik, jembatan, sarana air bersih, jaringan irigasi dan dermaga. Aspek pengembangan sumber daya manusia melalui pembangunan ruang kelas, laboratorium, Puskesmas, pemenuhan alat-alat kesehatan, serta pelatihan tenaga kerja baru. Aspek ketiga, yang juga akan dibahas lebih jauh dalam artikel ini yakni pertumbuhan ekonomi, diwujudkan melalui bantuan sarana dan prasarana produksi 
pertanian, bantuan bisnis Usaha Mikro, Kecil dan Menengah (UMKM), bantuan pengembangan peternakan modern dan pembangunan kebun buah di daerah tertinggal.

Tulisan ini bukan bertujuan untuk mengevaluasi kinerja pemerintah dalam rangka pembangunan daerah tertinggal, melainkan untuk melihat kembali peran perempuan sebagai salah satu sumber daya pembangunan daerah melalui programprogram pemerintah maupun lembaga non-pemerintah dalam rangka percepatan pembangunan daerah tertinggal. Peraturan Pemerintah No. 78/2014 tentang Percepatan Pembangunan Daerah Tertinggal (PPDT), Pasal 35 mengatur tentang peran serta masyarakat dan pelaku usaha. PPDT dapat dibiayai dari swadaya masyarakat atau pelaku usaha lewat program-program kemitraan untuk daerah tertinggal. Pelaku usaha yang terlibat dalam PPDT akan mendapat insentif berupa kemudahan perizinan, permodalan dan kerja sama kemitraan.

Pembangunan selama ini identik dengan munculnya industri, daerah urban, migrasi penduduk hingga peningkatan taraf hidup sebuah masyarakat. Hal ini misalnya terlihat dalam sejarah, ketika industri gula pertama kali hadir di Jawa Timur. Sebelum Perang Dunia II, sekitar 75 persen tebu yang dihasilkan oleh koloni Belanda berasal dari pabrik gula di Jawa Timur-masing-masing dikelilingi oleh sekitar 1.000 hektar ladang tebu yang disewa dari desa-desa di sekitarnya. Sedangkan di daerah perbukitannya, perkebunan karet, teh, kopi dan tembakau sebanyak tidak kurang dari jumlah 264 didirikan atas 164.000 hektar lahan yang dikerjakan oleh tenaga kerja tidak terampil dari daerah dataran rendah yang padat penduduk (Peters 2013,4). Kebutuhan pekerja dari pembudidayaan tanaman yang bernilai jual tinggi tersebut kemudian menyebabkan ledakan penduduk di Pulau Jawa. Mengikuti kemajuan industri pertanian di masa itu, jalur kereta api ikut juga dibangun demi memfasilitasi perpindahan produk- 
produk pertanian dari satu desa ke desa lain. Daerah Surabaya sendiri sempat menjadi pusat kantor-kantor dagang dan pelayaran asal Belanda dan Pulau Jawa mempunyai infrastruktur transportasi terbaik se-Asia Tenggara (Peters 2013, 5).

Melengkapi gambaran tentang perubahan ekonomi masyarakat di atas, Angus Maddison (2007, 20-27) menyebutkan ada tiga hal yang mendongkrak peningkatan ekonomi dunia selama ini. Pertama, penaklukan wilayah-wilayah yang subur dan kaya sumber daya alam atau yang berpotensi untuk mengakomodasi perpindahan populasi, tani, dan ternak. Kedua, perdagangan internasional dan perpindahan modal. Terakhir, teknologi dan inovasi kelembagaan. Tanpa peningkatan dalam teknologi maritim dan institusi komersial, misalnya, pembukaan pasar dunia tidak mungkin tercapai. Kemajuan teknis di banyak bidang terjadi karena adanya publikasi pengetahuanpengetahuan baru. Perbankan, kredit, pasar valuta asing, manajemen keuangan dan fiskal, akuntansi, asuransi dan tata kelola perusahaan merupakan komponen penting dari keberhasilan Eropa dalam membuka pasar dunia.

Di sisi lain, pola pembangunan yang ada selama ini selalu menghasilkan ketidaksetaraan: negara maju dengan negara berkembang, perkotaan dengan pedesaan, kawasan elit dan kawasan kumuh, laki-laki dan perempuan. Karenanya, pemerataan pembangunan yang berdasarkan keadilan gender sudah selayaknya menjadi fokus berbagai pihak. Pembangunan yang membawa kesejahteraan masyarakat tidak hanya mengacu kepada tingkat pendapatan yang tinggi, tetapi juga dalam kualitas-kualitas hidup yang lain seperti kesehatan, pendidikan, akses terhadap informasi dan preferensi pribadi. Di tataran individu, kebanyakan perempuan di daerah tertinggal belum dan tidak akan pernah terlibat dalam pembangunan. Pemekaran bisnis kapitalis ke berbagai tempat di seluruh dunia-berikut aliran teknologi, pekerja dan modalnya-tidak lantas 
berpengaruh positif untuk kesejahteraan perempuan, apalagi perempuan di pedesaan ketika perdagangan dan aliran modal memasuki daerah mereka.

Perempuan pedesaan cenderung terlibat sebagai tenaga kerja jasa berpendapatan rendah yang menyatu dalam globalisasi ekonomi akibat munculnya kebutuhan dan gaya hidup baru dari tenaga kerja profesional berpendapatan tinggi di kota-kota besar (Yesyca 2013, Sassen 2002). Perempuan pedesaan dan teknologi bahkan sempat tidak menjadi kombinasi yang cocok. Misalnya, di saat mekanisasi pertanian muncul, maka buruh tani perempuan di pedesaan Jawa-lah yang terdepak dari pekerjaannya dan harus mencari penghidupan di luar pertanian; dengan tambahan catatan, kegiatan industri di luar pertanian pun sedikit sekali yang terbuka bagi buruh perempuan (Mulyanto 2009). Hal yang menarik adalah hari ini justru ada dukungan sangat tinggi terhadap pengembangan bisnis milik perempuan.

Berbagai program perbankan, kampanye Lembaga Swadaya Masyarakat dan organisasi internasional, serta pemerintah nasional maupun lokal ikut berkontribusi terhadap munculnya fenomena usaha milik perempuan. Adalah 'branchless banking', 'mobile banking', 'fintech' ('financial technology') yang menjadi tren baru di berbagai tempat termasuk di Indonesia. Terma yang berbeda-beda ini sesungguhnya merupakan satu tema, yakni penetrasi industri keuangan digital dengan memanfaatkan teknologi komunikasi seluler atau telepon seluler (ponsel) ke daerah-daerah pelosok, terutama di sektor usaha mikro. Berbagai lembaga yang mengusung program semacam ini umumnya berfokus kepada perempuan yang tidak bisa mendapatkan pembiayaan dari perbankan oleh karena mereka tinggal di daerah-daerah yang tidak terjangkau layanan bank, tidak memiliki sesuatu untuk diagunkan dan terbatas dalam mobilitas (Indonesia 
Fintech Festival and Conference 2016, Nugroho dan Chowdury 2015, FII Tanpa Tahun, Bank Indonesia Tanpa Tahun).

\section{MENCERMATI POSISI PEREMPUAN DALAM PEMBANGUNAN}

Dalam ekonomi dunia yang semakin saling bergantung dan terkoordinasi saat ini, perempuan di daerah nampaknya menjadi primadona dan tidak jarang pula diklaim sebagai kunci pembangunan ekonomi. Pertanyaan yang penting untuk dijawab: Benarkah mereka sungguh dapat berpartisipasi di dalamnya? Atau perempuan di desa justru direduksi perannya (dengan ide-ide, tujuan dan keterampilan mereka sendiri), sekedar menjadi simbol pembangunan atau untuk kepentingan yang lain? Apakah dengan mendapatkan lebih banyak akses untuk berbisnis dan bantuan teknologi sama dengan lebih banyak pilihan, atau justru sebaliknya? Karena itu penelitian ini hendak menjawab pertanyaan: Di mana posisi perempuan dalam kebijakan percepatan pembangunan daerah tertinggal di Indonesia, khususnya di daerah Jawa Timur?

Untuk menjawab pertanyaan tersebut, penulis hendak menunjukkan interaksi antara gender dan ketimpangan ekonomi di empat kabupaten di Jawa Timur yang adalah daerah tertinggal. Penulis menggunakan data-data dari Badan Pusat Statistik dan dari lembaga resmi lainnya. Kemudian, penulis akan menganalisis kebijakan percepatan pembangunan dari pemerintah pusat dan daerah untuk melihat apakah kebijakan tersebut sudah tepat menyasar kebutuhan masyarakat di daerah tertinggal, sehingga dapat meningkatkan kesejahteraan masyarakat secara signifikan. Seluruh data mengenai kebijakan juga akan diperoleh melalui studi pustaka dengan memanfaatkan media online.

FEMINISME 
Feminisme oleh Tickner dan Sjoberg $(2011,5)$, dua orang penstudi Hubungan Internasional asal Amerika Serikat, dipahami sebagai dua fenomena yang saling terkait. Pertama, sebagai sebuah gerakan politis yang berfokus pada hak-hak perempuan dan emansipasi gender. Kedua, sebagai sebuah pendekatan ilmiah yang menggunakan lensa analisis gender untuk tidak hanya memahami lebih dalam mengenai perempuan dan gender; tetapi juga mengenai bagaimana sorotan kepada perempuan dan gender dapat membantu untuk memahami dunia secara umum.

Kontribusi utama Feminis adalah konsep gender, yang membedakannya dari jenis kelamin seorang individu secara biologis. 'Gender' dipahami sebagai sebuah konstruksi sosial sistematis yang membagi identitas, perilaku dan harapan atas seorang individu sebagai maskulin dan feminin. Karenanya, maskulinitas dan femininitas dipelajari (learned) oleh individu; bukannya ditentukan sedari awal ia lahir (given). Gender dapat pula melembaga dalam kehidupan sosial sehari-hari sebuah masyarakat.

Maskulinitas dan femininitas tidak bertentangan satu sama lain, tetapi justru saling terkait. Artinya, untuk memahami aktivitas laki-laki dan ideologi maskulinitas secara utuh diperlukan pemahaman atas aktivitas perempuan dan ideologi femininitas yang ada di masyarakat. Hal yang sama berlaku sebaliknya. Peterson (1992) berargumen bahwa pengetahuan atas realita sosial manusia selama ini berbasis pada pengalaman laki-laki secara eksklusif; sehingga melibatkan perempuan dalam berbagai hal tidak akan cukup untuk membawa kesetaraan gender. Diperlukan upaya untuk merekonstruksi pemahaman tentang realita sosial, seperti misalnya ekonomi, politik dan lain-lain, agar tak lagi berdasar pada kepercayaan-kepercayaan mengenai laki-laki dan perempuan yang terdistorsi karena hirarki gender yang melekat dalam suatu 
masyarakat (yakni, eksklusivitas pengalaman laki-laki yang telah melembaga dalam masyarakat).

KONTEKS SOSIAL-EKONOMI MASYARAKAT DI EMPAT DAERAH TERTINGGAL DI JAWA TIMUR

Berdasarkan data Badan Pusat Statistik (BPS) Provinsi Jawa Timur tahun 2017, Indeks Pembangunan Manusia (IPM) tahun 2016 di Kabupaten Bondowoso 65,89; Kabupaten Situbondo 68,41; Kabupaten Bangkalan 69,77; dan Kabupaten Sampang 67,62. Keempatnya berada di bawah IPM Provinsi Jawa Timur di tahun yang sama 70,74. Keempat kabupaten berdasarkan data BPS Jawa Timur tahun 2017 juga memiliki jumlah penduduk perempuan yang lebih banyak dibandingkan penduduk laki-lakinya: Kabupaten Bondowoso (394.436 dibanding 374.476), Kabupaten Situbondo (346.592 dibanding 330.111), Kabupaten Bangkalan (507.105 dibanding 463.789), dan Kabupaten Sampang (491.162 dibanding 466.920).

Sementara itu, berdasarkan data BPS Jawa Timur tahun 2016 mengenai angka partisipasi sekolah menurut jenis kelamin dan kabupaten/kota, perbandingan tingkat partisipasi sekolah perempuan dan laki-laki sangat bervariasi di keempat kabupaten yang tertinggal. Angka partisipasi sekolah merupakan proporsi penduduk pada kelompok umur jenjang pendidikan tertentu yang masih bersekolah terhadap penduduk pada kelompok umur tersebut (BPS 2017d, 24). Tingkat partisipasi sekolah perempuan sama dengan laki-laki hanya terjadi di Kabupaten Bondowoso untuk tingkat Sekolah Dasar (100 persen). Di kabupaten yang sama, jenjang pendidikan SMP/MTs dan SMA/MA, perempuan lebih rendah partisipasinya dibandingkan laki-laki: SMP/MTs (94,90 dibanding 96,66) dan SMA/MA (56,08 dibanding 51,39). Di satu kabupaten tertinggal yang lain, partisipasi sekolah laki-laki lebih tinggi daripada perempuan di 
semua jenjang. Kabupaten Situbondo: SD/MI (97,34 dibanding 97,03), SMP/MTs (97,69 dibanding 93,70), dan SMA/MA (71,08 dibanding 44,78).

Menariknya, Kabupaten Bangkalan memiliki tingkat partisipasi sekolah perempuan lebih tinggi dibanding laki-laki di semua jenjang. Kabupaten Bangkalan: SD/MI (100 dibanding 99,55), SMP/MTs (95,05 dibanding 90,84), dan SMA/MA (56,77 dibanding 54,34). Satu kabupaten tertinggal yang tersisa mempunyai tingkat partisipasi sekolah berdasarkan jenis kelamin yang variatif; di mana jenjang SD/MI dan SMA/MA mempunyai tingkat partisipasi sekolah laki-laki yang lebih tinggi dibanding perempuan, tetapi di jenjang SMP/MTS tingkat partisipasi sekolah perempuan lebih tinggi dibanding laki-lakinya. Perbandingan tingkat partisipasi sekolah laki-laki dan perempuan di Kabupaten Sampang: SD/MI (100 dibanding 99,70), SMP/MTs (90,91 dibanding 97,37), dan SMA/MA (55,68 dibanding 53,92).

Data tingkat partisipasi sekolah menurut jenis kelamin di empat kabupaten tertinggal di atas menunjukkan masih rendahnya tingkat pendidikan perempuan. Bahkan di Kabupaten Bangkalan yang tingkat partisipasi sekolah perempuannya tertinggi hingga ke jenjang SMA/MA di antara keempat kabupaten tertinggal $(56,77)$, jumlah ini menunjukkan bahwa hampir setengah dari penduduk perempuan di sana tidak melanjutkan pendidikan hingga ke tingkat SMA/MA. Tingkat pendidikan perempuan ini berbanding lurus dengan jumlah perkawinan usia anak (kurang dari 17 tahun) di empat kabupaten. Berdasarkan data persentase perempuan Jawa Timur usia 10 tahun ke atas yang kawin di bawah umur menurut kabupaten/kota tahun 20092016, Kabupaten Bangkalan didapati mempunyai persentase terkecil pada tahun 2016 dibandingkan ketiga daerah tertinggal lainnya yang persentasenya di atas 30 persen: 
Kabupaten Bangkalan (14,66), Kabupaten Sampang $(35,37)$, Kabupaten Situbondo $(43,79)$, Kabupaten Bondowoso $(50,20)$.

Hal yang memprihatinkan ialah bahwa di daerah dengan tingkat partisipasi sekolah perempuan-nya tertinggi di antara keempat kabupaten tertinggal di Jawa Timur ini, bahkan hingga ke jenjang SMA/MA, namun ternyata kondisi kesehatan perempuannya buruk. Kondisi ini tercermin dari tingginya Angka Kematian Bayi (AKB) di Kabupaten Bangkalan pada tahun $2016(48,90)$ dibandingkan tiga daerah lainnya: Kabupaten Sampang $(42,34)$, Kabupaten Bondowoso $(45,40)$ dan Kabupaten Situbondo $(48,47)$. Tingginya AKB di wilayah Madura, yang mencakup Kabupaten Bangkalan, Sampang, Pamekasan, Sumenep; dan wilayah Pandalungan, meliputi Kabupaten Pasuruan, Probolinggo, Bondowoso, Situbondo, dan Jember, pernah dibahas oleh Mochamad Setyo Pramono, Suci Wulansari dan Sutikno dalam riset mereka enam tahun yang lalu.

Data yang digunakan oleh Pramono, dkk. (2012) adalah data BPS Jawa Timur tahun 2007, yang menyebutkan bahwa kedua wilayah yang sering disebut sebagai wilayah tapal kuda itu dikelompokkan ke dalam wilayah dengan nilai AKB sangat tinggi, sebesar 43,92-69,66 kematian per 1000 kelahiran hidup. Artinya satu dekade setelahnya, hanya nilai AKB Kabupaten Sampang yang turun sehingga masuk dalam kelompok AKB tinggi (35,21-43,91 kematian per 1000 kelahiran hidup). Angka itu pun masih di atas 40 kematian per 1000 kelahiran hidup.

Nilai AKB yang sangat tinggi berarti risiko untuk anak yang lahir hidup namun mati sebelum ulang tahun pertamanya masih sangat besar di keempat kabupaten tertinggal di Jawa Timur. Angka ini menunjukkan bagaimana kondisi sosial dan ekonomi penduduk daerah tersebut. Perempuan, yang dalam budaya Madura memiliki 
aktivitas keseharian di sekitar anak-anaknya (Rakhmawati 2015, 61), merupakan kelompok yang kesejahteraannya paling minim diperhatikan. Data dari Pramono, dkk. (2012, 42-43), memperlihatkan persentase penolong terakhir persalinan ke tenaga kesehatan antarkabupaten/kota memadati Jawa Timur bagian barat; sementara di Jawa Timur bagian timur, wilayah Pedalungan dan wilayah Madura, memiliki persentase penolong terakhir persalinan ke tenaga kesehatan yang kecil.

Tabel 1. Angka Partisipasi Sekolah Empat Kabupaten Tertinggal di Jawa Timur Menurut Jenis Kelamin tahun 2011

\begin{tabular}{|l|c|c|c|c|c|c|}
\hline \multirow{2}{*}{ Kabupaten } & \multicolumn{2}{|c|}{$\begin{array}{c}\text { SD/MI } \\
\text { (7-12 tahun) }\end{array}$} & \multicolumn{2}{c|}{$\begin{array}{c}\text { SMP/MTs } \\
\text { (13-15 tahun) }\end{array}$} & \multicolumn{2}{c|}{$\begin{array}{c}\text { SMA/MA } \\
\text { (16-18 tahun) }\end{array}$} \\
\cline { 2 - 7 } & Laki-laki & Perempuan & Laki-laki & Perempuan & Laki-laki & Perempuan \\
\hline Bondowoso & 97,19 & 100,00 & 90,44 & 84,99 & 48,42 & 50,90 \\
\hline Situbondo & 97,32 & 97,98 & 81,73 & 79,58 & 63,60 & 46,25 \\
\hline Bangkalan & 96,70 & 96,62 & 85,90 & 70,86 & 52,86 & 46,65 \\
\hline Sampang & 95,88 & 98,67 & 85,86 & 84,72 & 52,36 & 32,33 \\
\hline
\end{tabular}

Sumber: BPS 2017e

Tabel 2. Angka Partisipasi Sekolah Empat Kabupaten Tertinggal di Jawa Timur Menurut Jenis Kelamin tahun 2016

\begin{tabular}{|l|c|c|c|c|c|c|}
\hline \multirow{2}{*}{ Kabupaten } & \multicolumn{2}{|c|}{$\begin{array}{c}\text { SD/MI } \\
\text { (7-12 tahun) }\end{array}$} & \multicolumn{2}{c|}{$\begin{array}{c}\text { SMP/MTs } \\
\text { (13-15 tahun) }\end{array}$} & \multicolumn{2}{c|}{$\begin{array}{c}\text { SMA/MA } \\
\text { (16-18 tahun) }\end{array}$} \\
\cline { 2 - 7 } & Laki-laki & Perempuan & Laki-laki & Perempuan & Laki-laki & Perempuan \\
\hline Bondowoso & 100,00 & 100,00 & 96,66 & 94,90 & 56,08 & 51,39 \\
\hline Situbondo & 97,34 & 97,03 & 97,69 & 93,70 & 71,08 & 44,78 \\
\hline Bangkalan & 99,55 & 100 & 90,84 & 95,05 & 54,34 & 56,77 \\
\hline Sampang & 100,00 & 99,70 & 90,91 & 97,37 & 55,68 & 53,92 \\
\hline
\end{tabular}

Sumber: BPS 2017b 
Data mengenai angka partisipasi sekolah keempat kabupaten tertinggal di atas menunjukkan bahwa dalam kurun waktu lima tahun terdapat indikasi bahwa tidak terjadi perubahan signifikan dalam hal partisipasi pendidikan masyarakat. Ada kenaikan angka partisipasi setelah lima tahun, namun kenaikannya kecil (lihat Tabel 1 dan 2 di atas). Kenaikan paling besar terjadi pada angka partisipasi sekolah perempuan pada jenjang pendidikan SMA/MA dari 32,33 pada tahun 2011 menjadi 53,92 pada tahun 2016 di Kabupaten Sampang. Angka tersebut berbanding lurus dengan AKB di Kabupaten Sampang, yang angkanya paling rendah di antara empat kabupaten tertinggal di Jawa Timur pada tahun 2016. Bahkan AKB Kabupaten Sampang turun cukup banyak dari 49,06 di tahun 2012 menjadi 42,34 di tahun 2016. Dari sini seolah dapat ditunjukkan bahwa tingkat pendidikan perempuan berbanding lurus dengan tingkat kesehatan ibu dan anak di daerah tertinggal. Hal ini dapat dilihat pada tabel 3.

Tabel 3. Angka Kematian Bayi (AKB) Empat Kabupaten Tertinggal di Jawa Timur tahun 2012-2016

\begin{tabular}{|l|c|c|c|c|c|}
\hline \multicolumn{1}{|c|}{ Kabupaten } & 2012 & 2013 & 2014 & 2015 & 2016 \\
\hline Bondowoso & 48,57 & 47,52 & 46,80 & 46,09 & 45,40 \\
\hline Situbondo & 49,48 & 48,92 & 48,76 & 48,62 & 48,47 \\
\hline Bangkalan & 49,14 & 48,81 & 48,82 & 48,85 & 48,90 \\
\hline Sampang & 49,06 & 47,02 & 45,49 & 43,95 & 42,34 \\
\hline
\end{tabular}

Sumber: BPS 2017c

Hal yang berbeda didapati di Kabupaten Bangkalan. Seperti Kabupaten Sampang, Kabupaten Bangkalan juga mempunyai kenaikan angka partisipasi sekolah perempuan pada jenjang pendidikan SMA/MA dalam waktu lima tahun yang cukup signifikan, yakni dari 46,65 pada tahun 2011 menjadi 56,77 pada tahun 2016. Namun demikian, AKB Kabupaten Bangkalan tidak memperlihatkan perubahan yang signifikan dalam kurun 
waktu 2012-2016, yakni 49,14 pada tahun 2012 menjadi 48,90 pada tahun 2016 (lihat Tabel 3). Sehingga, dapat dikatakan kenaikan tingkat partisipasi sekolah perempuan tidak berdampak terhadap tingkat kesehatan individu perempuan dan anak-anak, anggota keluarga yang terdekat dengan perempuan dalam budaya Madura tersebut.

Fakta di atas mengindikasikan belum efektifnya sistem pelayanan rujukan bagi ibu dan bayi yang baru lahir di daerah tertinggal. Akses kepada pelayanan kesehatan ibu dan bayi yang berkualitas masih sangat terbatas. Hal ini mengonfirmasi temuan Pramono, dkk. $(2012,45)$ bahwa di wilayah Madura dan Padalungan, tradisi budaya dan kebiasaan masyarakat berpengaruh besar bagi perempuan, khususnya ibu hamil dan yang baru melahirkan. Peran tradisi masyarakat yang lebih besar daripada pendidikan menuntut pentingnya pola pembangunan yang dapat mengubah tradisi di masyarakat. Tanpanya, pembangunan tidak akan membawa dampak yang signifikan bagi kelompok perempuan di empat daerah tertinggal tersebut.

Masyarakat Madura di Kabupaten Bangkalan dan Sampang, memiliki sistem budaya yang cenderung patriarkhis meskipun menganut paham matrilineal. Pada masyarakat Madura, kepemilikan rumah jatuh kepada keluarga perempuan. Meski demikian, posisi dan peran perempuan terbatas dalam keluarga mereka, khususnya dalam pengambilan keputusan. Perempuan didorong untuk mengambil peran-peran domestik, sementara laki-laki kepada peran-peran publik di luar rumah. Ketika mengerjakan peran-peran domestiknya pun, perempuan beraktivitas untuk mewujudkan tanggung jawab dan pengabdiannya kepada keluarga-tidak untuk dirinya sendiri (Rakhmawati 2015, 71-72). Akibat akses yang terbatas dan nilai-nilai budaya patriarkhis ini, pengelolaan sumber-sumber daya dalam keluarga, apalagi di masyarakat yang merupakan ruang publik, menjadi wajar jika tidak menyasar kepada 
kesejahteraan perempuan. Padahal, aktivitas-aktivitas domestik perempuan itulah yang menopang keseluruhan aktivitas ekonomi dalam keluarga dan masyarakat Madura.

Setelah melihat konteks sosial ekonomi dan bagaimana gender melekat dalam tradisi dan budaya masyarakat setiap daerah, termasuk di daerah-daerah tertinggal di Jawa Timur, bagian berikutnya akan membahas tentang kebijakan percepatan pembangunan di daerah tertinggal. Penulis akan menganalisis kebijakan percepatan pembangunan dari pemerintah pusat dan daerah untuk melihat apakah kebijakan tersebut sudah tepat menyasar kebutuhan masyarakat di daerah tertinggal, sehingga dapat meningkatkan kesejahteraan masyarakat secara signifikan. Kebijakan yang abai akan gender yang melembaga di masyarakat tidak akan berdampak pada perbaikan kondisi ekonomi antara laki-laki dan perempuan yang timpang di dalamnya.

BIAS GENDER DALAM PROGRAM PPDT BERFOKUS INDUSTRI RUMAHAN HINGGA KREDIT MIKRO MELALUI PONSEL

Di tingkat nasional, pemerintah mempunyai kebijakan untuk meningkatkan peran perempuan dalam menaikkan pendapatan rumah tangga. Berdasarkan Peraturan Menteri Pemberdayaan Perempuan dan Perlindungan Anak Republik Indonesia Nomor 2 Tahun 2016, Kementerian Pemberdayaan Perempuan dan Perlindungan Anak (KPPPA) mempunyai program 'Pembangunan Industri Rumahan untuk Meningkatkan Kesejahteraan Keluarga Melalui Pemberdayaan Perempuan.' Program ini merupakan tindak lanjut kebijakan Peningkatan Produktivitas Ekonomi Perempuan (PPEP) yang berlangsung dari tahun 2004-2011. Dari hasil evaluasi dan kajian tindak lanjut terhadap kebijakan PPEP, KPP-PA kemudian berfokus kepada Industri Rumahan (IR). IR yang dilakukan perempuan dianggap dapat membantu peningkatan kesejahteraan keluarga, 
menyerap dan menciptakan tenaga kerja, dan mengurangi keinginan tenaga kerja untuk bermigrasi menjadi tenaga kerja informal.

Menurut KPP-PA, perempuan dilihat berkontribusi besar bagi perkembangan perekonomian nasional pascakrisis finansial global 2008, di mana pada periode 20082009 Indonesia mengalami dampak krisis berupa migrasi pekerja dari sektor formal ke sektor informal, seiring dengan penutupan dan efisiensi/rasionalisasi sejumlah perusahaan, khususnya yang bergerak di sektor industri dan jasa. Sektor informal terbukti memiliki kedudukan yang penting sebagai sumber penghidupan bagi sebagian besar masyarakat Indonesia (KPP-PA 2012, 2). Di dalam sektor yang unorganized, unregulated dan unregistered dengan jumlah lebih dari 30 juta pengusaha ukuran mikro, kecil dan menengah ini, 60 persennya adalah perempuan (Iskandar 2017).

Perempuan wirausaha tersebut pada umumnya dilihat mengalami kendala permodalan sekaligus keunggulan dalam hal keleluasaan untuk bekerja di rumah sembari mengerjakan tugas sebagai seorang istri dan/atau ibu (Nugroho dan Chowdury 2015, 88). Menteri PP-PA periode 2009-2014 Linda Gumelar mengatakan bahwa perempuan wirausaha dapat "mengatur keuangan rumah tangga sambil memenuhi gizi keluarga. ...menjadi sumber penghasilan keluarga. ...dalam satu wilayah kecil dapat membentuk komunitas, dan komunitas-komunitas perempuan ini bisa memproduksi dan memasarkan produk secara bersama-sama" (Dolorosa 2013).

KPP-PA melihat bahwa IR dapat meningkatkan peluang perempuan untuk lebih terlibat secara aktif dalam berbagai kegiatan ekonomi yang memberikan penghasilan. Perempuan pun diharapkan dapat meningkatkan kontribusinya dalam peningkatan kesejahteraan ekonomi keluarga dan pada gilirannya berkontribusi dalam pengembangan ekonomi masyarakat lokal. Dengan cara ini, KPP-PA melihat perempuan 
akan dapat meningkatkan posisi tawar menuju keadilan dan kesetaraan gender. KPP-PA kemudian giat mendorong munculnya wirausaha perempuan melalui IR sebagai strategi utama pembangunan di daerah-daerah tertinggal, terpencil dan terluar (KPP-PA 2016, ii).

Senada dengan pemerintah pusat, di tingkat pemerintahan daerah, tepatnya di Provinsi Jawa Timur di mana Usaha Mikro, Kecil dan Menengah menjadi penyumbang terbesar terhadap Produk Domestik Regional Bruto (PDRB) selama Januari-Agustus 2016 yaitu sebanyak 54,98 persen, pemerintah daerah pun lantas berupaya untuk mengembangkan sektor UMKM dengan mengembangkan jumlah koperasi agar bisa mendukung permodalan UMKM (Amaluddin 2016). Mantan gubernur Jawa Timur, Soekarwo, mendorong peran serta perempuan dalam rangka mendukung pembangunan daerah, salah satunya dengan cara mendorong organisasi perempuan untuk menjadi Lembaga Keuangan Masyarakat (LKM) di pedesaan selain koperasi wanita. Menurut beliau, kegiatan LKM di pedesaan sangat baik untuk menghentikan lintah darat, memberdayakan ekonomi perempuan lewat pembiayaan industri primer di sektor UMKM seperti berjualan makanan kering, sekaligus menggerakkan ekonomi pedesaan (Tanpa Nama 2016b). 'Sekali dayung, dua-tiga pulau terlampaui' seolah menjadi semangat tren inklusi keuangan perempuan pedesaan ini.

Perempuan pedesaan umumnya dipandang mengalami kendala permodalan akibat tidak adanya pekerjaan formal yang ditandai dengan penghasilan tetap per bulan. Sementara, tersedianya slip pendapatan bulanan merupakan salah satu syarat pinjaman ke bank formal. Akses terhadap layanan keuangan yang terbatas inilah yang kemudian menjadi alasan gencarnya industri perbankan berbasis teknologi merambah hingga ke daerah-daerah tertinggal (Irijanto 2015). Jika di perkotaan perempuan pelaku 
UMKM dibekali dengan penguasaan teknologi digital seperti media sosial untuk memanfaatkan pasar on-line agar menembus wilayah yang lebih luas di Indonesia dan bahkan dunia (Iskandar 2017), perempuan pedesaan dibekali dengan teknologi untuk mengakses produk-produk industri perbankan, khususnya kredit mikro dan microfinance ${ }^{1}$, agar mampu menjadi agen pemulihan ekonomi rumah tangga hingga daerah.

Menurut Soekarwo, peran perempuan dalam pembangunan yang ada di Provinsi Jawa Timur sangat penting dan, "perempuan juga harus memperhatikan kesejahteraan keluarga (cetak miring adalah penekanan dari penulis untuk menunjukkan adanya bias gender terhadap tanggung jawab perempuan)." Hal ini diungkapkan oleh mantan gubernur Jawa Timur tersebut saat memberikan sambutan dalam Rakerda Tim Penggerak PKK Provinsi dan Kabupaten/Kota se-Jawa Timur pada tahun 2015. Meskipun beliau mengatakan bahwa kebijakan pengarustamaan gender menjadi sebuah prioritas pembangunan, namun pernyataan beliau tersebut menunjukkan masih adanya bias gender dalam kebijakan pemerintah. Beliau mengemukakan, "perempuan mampu menjadi akuntan keluarga, penanggung jawab pekerjaan domestik, menjadi simpul jaringan sosial untuk transfer sosial pada masa kritis dan krisis." Dengan pandangan seperti ini, Soekarwo meyakini bahwa perempuan harus digerakkan menjadi potensi ekonomi. Di bawah Soekarwo, arah kebijakan pemberdayaan dan perlindungan perempuan di Jawa Timur adalah pada peningkatan dan perluasan jaringan usaha dan akses permodalan bagi perempuan melalui pengembangan koperasi wanita dan lembaga keuangan mikro (LKM) fungsional (Setiawan 2015). 
TEKNOLOGI INKLUSI KEUANGAN BAGI WIRAUSAHA PEREMPUAN: PERAN PARSIAL PEREMPUAN SEBAGAI SUMBER DAYA PEMBANGUNAN DAERAH

Lekatnya perempuan pedesaan, kredit UMKM dan teknologi yang memfasilitasinya berasal dari ide bahwa mendorong perempuan di daerah-daerah tertinggal tersebut untuk dapat mengakses pasar akan meningkatkan pendapatan rumah tangga, menggerakkan perekonomian daerah, dan pada gilirannya juga akan berkontribusi terhadap perekonomian nasional. Namun demikian, gagasan ini patut untuk ditinjau ulang. Bukan bermaksud untuk mengevaluasinya, melainkan untuk mencermati apakah logika instrumentalis ini sungguh dapat memberdayakan perempuan atau justru mengukuhkan struktur ketimpangan ekonomi berbasis gender yang selama ini mendiskriminasi dan memarjinalkan perempuan di daerah-daerah tertinggal.

Berkaca dari uraian program-program PPDT dari berbagai institusi yang telah disebutkan di atas, dapat dipahami bahwa seluruh gagasan tersebut secara spesifik berasumsi bahwa teknologi inklusi keuangan bagi perempuan disediakan karena perempuan layak kredit atau creditworthy. Karenanya, perempuan "diperjuangkan" dan difasilitasi dengan teknologi agar mereka dapat menjadi konsumen produk-produk kredit ini (kembali mengingat bahwa pada konteks yang lain, perempuan bukan pasangan yang tepat bagi teknologi). Perempuan juga didorong untuk berwirausaha agar dapat menghasilkan nilai lebih dari aktivitas reproduksi dan mengembalikan pinjaman beserta bunganya. Di sini nampak bahwa konteks ekonomi yang mendasari perbedaan posisi subjek perempuan menjadi lebih "akrab” dengan teknologi adalah kapitalisme industri keuangan, bukan lagi kapitalisme industri manufaktur. Ini pada gilirannya akan mengukuhkan pembatasan kontrol perempuan sebagai pengelola 
keuangan dalam keluarga, lengkap dengan tanggung jawabnya sebagai pemelihara keluarga.

Beban berlipat ganda diletakkan di bahu perempuan pedesaan untuk memelihara keluarganya, menjadi pengelola keuangan keluarga, sekaligus untuk menghasilkan nilai lebih bagi industri keuangan yang masuk ke daerahnya. Bagaimana perempuan memiliki tingkat pengembalian kredit (repayment) yang lebih tinggi dibanding laki-laki menjadi salah satu justifikasi. Di dalamnya melekat "tanggung jawab" perempuan terhadap keluarganya (atas kesehatan dan pendidikan anak, misalnya, yang seringkali dilihat memiliki tanggung jawab lebih dari suaminya) yang memungkinkan perempuan di daerah-daerah tertinggal untuk menjadi konsumen kredit yang baik.

Dengan meninjau ulang konteks ekonomi yang mendasari pemberdayaan ekonomi perempuan dan rumah tangga pada program-program PPDT di atas, menjadi nampak bahwa program pemberdayaan perempuan yang demikian sebenarnya cukup bermasalah untuk dipraktikkan. Sebagai program yang seharusnya memberdayakan perempuan arti pemberdayaan yang diupayakan melalui program ini adalah, lebih tepatnya, membuat perempuan pedesaan bekerja lebih baik bagi industri keuangan berbasis teknologi yang kian bertumbuh pesat hari-hari ini di Indonesia. Kenyataan ini cukup meresahkan karena justru program-program maupun pelaku yang mendorong wirausaha perempuan dan memfasilitasi kredit bagi mereka tersebut cenderung melihat pada stereotip perempuan dan laki-laki sehingga sangat rentan untuk bias dan diskriminatif terhadap perempuan pedesaan. Asumsi yang berlaku adalah hanya terdapat satu kategori perempuan (dan laki-laki) di daerah tertinggal, yang tidak berketerampilan dan berpendidikan, cocok untuk mengerjakan industri primer dan 
bahwa mereka membutuhkan bantuan keuangan untuk memperlancar keuangan rumah tangga mereka sebagai solusi atas permasalahan sosial yang mereka hadapi.

Perempuan pedesaan juga dilihat akan dapat mencapai status yang lebih tinggi dalam hirarki relasi sosial dalam rumah tangga dan masyarakat yang lebih luas dengan cara memperoleh pendapatan tambahan bagi keluarganya. Alih-alih diberdayakan, perempuan pedesaan justru mendapat beban agar dapat berkontribusi bagi pembangunan daerah, yang dimaknai sempit dengan peningkatan pendapatan daerah. Peran perempuan bagi pembangunan dibatasi pada menyumbang angka PDB daerah. Sementara dalam Permen PP-PA No. 2/2016, 'pemberdayaan perempuan' didefinisikan sebagai 'upaya terstruktur untuk mewujudkan kesetaraan gender dalam hal akses, partisipasi, kontrol, dan manfaat dalam pembangunan dan penguasaan sumber daya dalam rangka peningkatan kualitas hidup dan peningkatan peran perempuan.' Program-program inklusi keuangan perempuan wirausaha untuk tujuan percepatan pembangunan daerah tertinggal yang ada dan yang seharusnya memberdayakan perempuan—sebagaimana seharusnya sebuah pembangunan itu berdampak positif bagi seluruh anggota masyarakat—justru menjadi problematis.

Gambaran warga laki-laki maupun perempuan yang dihadirkan dalam programprogram tersebut sangat stereotip dan rawan terhadap pandangan yang bias dan diskriminatif dengan mengasumsikan hanya ada satu kategori perempuan (dan lakilaki) di daerah-daerah tertinggal di Indonesia, yang membutuhkan bantuan modal ekonomi untuk meningkatkan kesejahteraan hidup mereka. Ketika menggunakan kata 'perempuan,' program-program dan pelakunya mengacu kepada sekelompok orang yang bercirikan perempuan secara biologis, pasif, enggan mengambil risiko, marjinal, tidak melek keuangan, domestik/patuh, cocok bagi kerja-kerja informal, dan kolektif. 
Sedangkan laki-laki yang tidak sering muncul dalam diskusi mengenai programprogram PPDT yang berfokus pada wirausaha perempuan dan pemberian kredit usaha mikro di daerah-daerah tertinggal diasumsikan sebagai kelompok jenis kelamin kebalikannya, yang cakap di ranah publik, lebih cocok untuk melakukan kerja formal, dominan, individual, melek keuangan, aktif dan pengambil risiko.

Dikotomi di atas kembali mengulang hirarki berbasis gender antara perempuan dan laki-laki, sehingga terlihat jelas bahwa program-program pemberdayaan ekonomi perempuan semacam ini belum tentu memberdayakan perempuan dalam arti mentransformasi relasi hirarkis antara laki-laki dan perempuan dalam mengelola sumber daya ekonomi. Program-program tersebut jelas dapat membentuk subjek perempuan wirausaha yang kompetitif, namun tidak serta-merta menyentuh hirarki gender dalam relasi ekonomi rumah tangga maupun dalam masyarakat. Programprogram semacam ini mengulang kembali pembagian kerja rumah tangga laki-laki dan perempuan, dan bukannya mempermasalahkan kekurangtertarikan laki-laki pada isu kesehatan dan pendidikan anak.

Pesan yang kuat dari berbagai program tersebut adalah bahwa perempuan berpendapatan rendah namun aktif berusaha mikro tersebut adalah target yang "menjanjikan" untuk industri jasa kredit perbankan. Pesan ini berisiko dan sangat problematis bagi perempuan. Berisiko, karena dapat meneguhkan subordinasi terhadap perempuan di dalam lingkup rumah tangga. Program pemberdayaan ekonomi perempuan tersebut tidak menyinggung tanggung jawab laki-laki dalam pekerjaan rumah tangga, tetapi justru menambah beban perempuan dalam pekerjaan rumah tangga sekaligus mencari nafkah. Kesetaraan gender menjadi tujuan sampingan dalam rangka mewujudkan pemajuan ekonomi; bukannya untuk pemajuan perempuan. 
Pertama-tama, perlu disadari bahwa otonomi perempuan dalam banyak kasus tidak berjalan seiring dengan meningkatnya kontribusi perempuan menafkahi keluarga. Justru, seringkali laki-laki merasa terancam ketika perempuan ikut menafkahi keluarga dan mempunyai penghasilan sendiri yang lebih besar dibandingkan penghasilannya. Akibatnya, muncul kekerasan domestik, perkosaan, penelantaran, dan lain-lain bahkan dalam keluarga yang sejahtera sekalipun. Di sini terlihat adanya problem sistemik dalam lingkup rumah tangga yang menyebabkan subordinasi perempuan, namun hal ini belum disasar oleh program pemberdayaan ekonomi perempuan. Perempuan yang didorong untuk dapat bersaing dengan laki-laki dalam berbisnis atau mengembangkan Industri Rumahan, tanpa menghiraukan adanya hirarki berbasis gender dalam keluarga dan masyarakat yang patriarkal justru akan cenderung mendorong munculnya praktik kekerasan terhadap salah satu pihak dan mereproduksi ketidaksetaraan berbasis gender di dalam keluarga dan masyarakat.

Kedua, pesan semacam itu bersifat problematis karena kata dalam tanda kutip, "menjanjikan," dilekati oleh logika tertentu yang bekerja untuk sebuah proses ekonomi masyarakat yang mensyaratkan ketimpangan dan perhitungan untung dan rugi dalam mencapai tujuannya, yakni ekonomi kapitalisme. Sedangkan di banyak daerah di Indonesia, proses ekonomi masyarakat tidak berbasis pada perhitungan untung dan rugi namun pada nilai-nilai kearifan lokal yang beragam dan umumnya bertujuan untuk pemeliharaan, tidak hanya komunitas lokal setempat, tetapi juga lingkungan alam tempat tinggal mereka. Ekonomi lokal dan global yang kontras ini dapat berbenturan dan tidak jarang berujung kepada kekerasan kepada pihak yang subordinat dalam relasi kuasa dan minor dalam jumlah. 
Di sisi lain, adalah mitos jika dikatakan perempuan akan membuat negara keluar dari kemiskinan. Pembangunan berkelanjutan dalam artian mempertimbangkan kebutuhan generasi-generasi selanjutnya membutuhkan tata kelola pemerintahan yang bijak dan relasi berbagai pemangku kepentingan yang berkeadilan. Dengan menjadikan perempuan sebagai target industri jasa keuangan untuk percepatan pembangunan daerah tertinggal, justru peranan tidak diberikan kepada perempuan untuk membangun dirinya sendiri. Sebaliknya, kontribusi perempuan terbatas pada peluang untuk meningkatkan pendapatan rumah tangga. Perempuan "bebas" berusaha sepanjang ia terus berkontribusi terhadap peningkatan ekonomi keluarga.

\section{KESIMPULAN}

Posisi perempuan dalam program-program PPDT sebagai agen pembangunan bersifat problematis oleh karena program-program tersebut lebih berorientasi menciptakan subjeksubjek wirausaha perempuan tanpa menyentuh permasalahan hirarki berbasis gender dalam ekonomi rumah tangga dan masyarakat di daerah tertinggal pada umumnya, termasuk di Jawa Timur yang kental dengan budaya "perempuan sebagai teman di belakang" atau yang sering dikenal dengan istilah "konco wingking." Dengan demikian menjadikan perempuan pedesaan sebagai agen pembangunan justru dapat berakibat tidak memberdayakan mereka sama sekali dalam pembangunan daerah.

Dengan bantuan modal dan fasilitas dari pemerintah ataupun pelaku usaha, perempuan pedesaan dapat menjadi motor penggerak ekonomi daerah dan menyumbang nilai Produk Domestik Regional Bruto kabupaten tertinggal secara efektif. Akan tetapi, perlu dicermati sekali lagi bahwa program-program PPDT yang menitikberatkan peran perempuan dalam pertumbuhan ekonomi daerah tidak lantas memberdayakan perempuan dalam arti 'mewujudkan kesetaraan gender dalam hal akses, partisipasi, kontrol, dan manfaat dalam 
pembangunan dan penguasaan sumber daya dalam rangka peningkatan kualitas hidup dan peningkatan peran perempuan.' Hal ini dikarenakan peran perempuan dalam membangun daerahnya justru dibatasi pada menghasilkan pendapatan tambahan untuk keluarga melalui kerja rumahan. Perempuan tetap kurang berperan dalam aspek-aspek pembangunan yang lain seperti penyediaan sarana-prasarana kesehatan dan pendidikan, pembangunan infrastruktur, serta pengembangan sumber daya manusia.

Investasi kepada perempuan juga dianggap menguntungkan, sebab perempuan (dituntut) lebih bertanggung jawab atas keluarganya dibandingkan laki-laki--kalau bukan terintimidasi oleh kontrol suami atas rumah tangga--dan karenanya tingkat pengembalian pinjaman perempuan lebih tinggi dibandingkan laki-laki. Pemberdayaan perempuan di dalam program-program tersebut di atas berarti mendorong perempuan untuk mampu memproduksi nilai lebih di samping bertanggung jawab atas pekerjaan rumah tangga (memberikan beban ganda bagi perempuan), memperoleh pendapatan tambahan--ataupun utama--bagi keluarga, dan menghasilkan keuntungan, yang dianggap sebagai kunci pembangunan. Perempuan dikatakan dapat sukses berperan dalam pertumbuhan ekonomi hanya jika perempuan cukup "bijak," "ulet," “sabar," "tekun," "ikhlas," "berkemauan tinggi," dan "tidak egois" untuk membagi waktu terkait "peran” gandanya. Sebagai penutup, penulis merekomendasikan agar lebih banyak program-program pemberdayaan perempuan sebagai agen pembangunan daerah tertinggal yang dengan hati-hati menilik kondisi ketimpangan ekonomi berbasis gender yang ada dalam masyarakat setempat sebelum merumuskan bentuk-bentuk pemberdayaan ekonomi yang akan dijalankan.

\section{Catatan}

Program-program inklusi keuangan di tingkat global sebagai stimulus pertumbuhan ekonomi telah mengalami banyak perkembangan. Konsep 'kredit mikro' atau microcredit di banyak tempat telah bergeser menjadi 'microfinance,' yang mencerminkan fokus utama masa kini ada pada mendorong pasar keuangan bekerja lebih baik bagi kelompok masyarakat miskin dengan tidak hanya terbatas menyediakan 
layanan keuangan berupa kredit skala mikro; tetapi juga asuransi dan jasa-jasa keuangan lainnya bagi kelompok ini.

\section{REFERENSI}

Amaluddin. 2016. "2016, UMKM Sumbang PDRB Jatim Rp 900 Triliun.” Metronews.com, 31 Agustus. Diakses pada 23 Februari 2017. http://m.metrotvnews.com/ekonomi/mikro/ybD1oPjk-2016-umkm-sumbangpdrb-jatim-rp900-triliun.

Arta, Camely. 2018. "Kesetaraan Gender dalam Akses Kerja untuk Akhiri Kemiskinan Perempuan." Magdalene.co, 28 Maret. Diakses pada 28 Juli 2018. https://magdalene.co/news-1681-kesetaraan-gender-dalam-akses-kerja-untukakhiri-kemiskinan-perempuan.html.

Bank Dunia. 2001. "Supply and Demand in Microfinance," dalam The Microfinance Revolution: Sustainable Finance for the Poor, Washington DC: The World Bank, 641.

Badan Pusat Statistik Provinsi Jawa Timur. 2017a. "Persentase Perempuan Jawa Timur Usia 10 Tahun Ke Atas yang Kawin di Bawah Umur (Kurang dari 17 Tahun) menurut Kabupaten/Kota, 2009-2016." Diakses pada 28 Juli 2018. https://jatim.bps.go.id/statictable/2017/06/09/465/persentase-perempuanjawa-timur-usia-10-tahun-ke-atas-yang-kawin-di-bawah-umur-kurang-dari-17tahun-menurut-kabupaten-kota-2009-2016-.html.

. 2017b. "Angka Partisipasi Sekolah Jawa

Timur Menurut Jenis Kelamin dan Kabupaten/Kota, 2016.” Diakses 28 Juli 2018. https://jatim.bps.go.id/dynamictable/2017/09/19/92/angka-partisipasisekolah-jawa-timur-menurut-jenis-kelamin-dan-kabupaten-kota-2016.html.

2017c. "Angka Kematian Bayi (AKB) Penduduk Jawa Timur Menurut Kabupaten/Kota, 2012-2016.” Diakses 28 Juli 2018. https://jatim.bps.go.id/statictable/2017/06/07/389/angka-kematianbayi-akb-penduduk-jawa-timur-menurut-kabupaten-kota-2012-2016.html.

. 2017d. Statistik Kesejahteraan Rakyat Provinsi Jawa Timur 2017. Surabaya: BPS Provinsi Jawa Timur.

2017e. "Angka Partisipasi Sekolah Jawa Timur Menurut Jenis Kelamin dan Kabupaten/Kota, 2011.” Diakses 28 Juli 2018. https://jatim.bps.go.id/statictable/2015/02/16/219/angka-partisipasi-sekolahaps-jawa-timur-menurut-jenis-kelamin-dan-kabupaten-kota-2011.html.

Bank Indonesia. Tanpa Tahun. "Keuangan Inklusif: Layanan Keuangan Digital (LKD)." $\begin{array}{lllll}\text { Diakses } & \text { pada } & 23 & \text { Februari } & \end{array}$ http://www.bi.go.id/id/perbankan/keuanganinklusif /program/lkd/Contents/Default.aspx. 
Diop, Makhtar. 2015. "How Empowering Women Can Help End Poverty in Africa." The World Bank, 28 Januari. Diakses pada 28 Juli 2018. http://blogs.worldbank.org/nasikiliza/how-empowering-women-can-help-endpoverty-africa.

Dolorosa, Gloria Natalia. 2013. "Perempuan Entrepreneur Berkembang Bersama Komunitas." Bisnis Indonesia, 22 Juli. Diakses pada 16 Februari 2017. http://koran.bisnis.com/read/ 20130722/250/152376/perempuanentrepreneur-berkembang-bersama-komunitas.

Elsynosa, Folda. 2018. "Perempuan Indonesia Berperan Penting Tingkatkan Ekonomi Negara." Voinews.id, 3 Juli. Diakses pada 28 Juli 2018. http://voinews.id/indonesian/index.php/component/k2/item/3533perempuan-indonesia-berperan-penting-tingkatkan-ekonomi-negara.

Financial Inclusion Insights (FII). Tanpa Tahun. “Gender.” Diakses pada 16 Februari 2017. http://finclusion.org/topic/gender.html.

Indonesia Fintech Festival and Conference. 2016. "Ringkasan Sesi, October 2016." $\begin{array}{llll}\text { Diakses } & \text { pada } & 23 & \text { Februari }\end{array}$ https://www.fintechfest.id/assets/docs/report ina (29112016).pdf.

Irijanto. 2015. "A Solution to Indonesian Remote Areas' Banking Access." Blog Kejora, 28 Mei. Diakses pada 29 Maret 2017. http://www.kejorahq.com/solutionindonesian -remote-areas-banking-access/

Iskandar, Eddy Dwinanto. 2017. "PPLIPI dan Telkom Genjot Digitalisasi Untuk Perempuan Pelaku UMKM.” SWA Online Magazine, 19 Februari. Diakses pada 27 Februari 2017. http://swa.co.id/swa/trends/pplipi-dan-telkom-genjotdigitalisasi-untuk-perempuan-pelaku-umkm.

Kementerian Pemberdayaan Perempuan dan Perlindungan Anak (KPP-PA). 2012. Kebijakan dan Strategi Peningkatan Produktifitas Ekonomi Perempuan (EPEP). Jakarta: KPP-PA.

Kementerian Pemberdayaan Perempuan dan Perlindungan Anak (KPP-PA). 2016. "Laporan Akhir Kajian Peran Perempuan dalam Penanggulangan Kemiskinan Melalui Kegiatan Industri Rumahan.” Diakses pada 16 Februari 2017. http://www.kemenpppa.go.id/lib/uploads/list/32803-kajian-peranperempuan-dalam.pdf.

Kementerian Dalam Negeri. 2016. "Kemendagri Telah Serahterimakan PNPM ke Kemendes." Siaran Pers, 7 Maret. Diakses pada 29 Juli 2018. http://www.kemendagri.go.id/news/2016/03/07/kemendagri-telahserahterimakan-pnpm-ke-kemendes.

Lagarde, Christine. 2016. "Women's Empowerment: An Economic Game Changer." Pidato oleh Christine Lagarde. International Monetary Fund, 14 November 2016. Diakses pada 
https://www.imf.org/en/News/Articles/2016/11/14/SP111416-Womens-

Empowerment-An-Economic-Game-Changer.

Lumanauw, Novy. 2015. "Ini 122 Kabupaten yang Ditetapkan sebagai Daerah Tertinggal." BeritaSatu.com, 8 Desember. Diakses pada 16 Februari 2017. http://www.beritasatu.com/nasional/328882-ini-122-kabupaten-yangditetapkan-sebagai-daerah-tertinggal.html.

Maddison, Angus. 2007. The World Economy: A Millennial Perspective. Paris:OICD.

Mulyanto, Dede. 2009. "Kapitalisme dan Penghidupan Perempuan di Pedesaan Jawa Kontemporer." Akatiga: Pusat Analisis Sosial, 7 Maret. Diakses pada 20 Februari 2017. $\quad$ http://www.akatiga.org/index.php/publikasi/artikel/item/153kapitalisme- dan-penghidupan-perempuan-di-pedesaan-jawa-kontemporer.

Nugroho, Lucky dan Syed Lutful Kabir Chowdhury. 2015. "Mobile Banking for Empowerment Muslim Women Entrepreneur: Evidence from Asia (Indonesia and Bangladesh)." Tazkia Islamic Finance and Business Review 9(1):83-100. Diakses pada 23 Februari 2017. $\underline{\text { http://www.tifbr- }}$ tazkia.org/index.php/TIFBR/article/ view/79/94.

Peraturan Menteri Pemberdayaan Perempuan dan Perlindungan Anak Republik Indonesia Nomor 2 Tahun 2016 tentang Pedoman Umum Pembangunan Industri Rumahan untuk Meningkatkan Kesejahteraan Keluarga Melalui Pemberdayaan Perempuan. Diakses pada 23 Februari 2017. http://idih.kemenpppa.go.id/.

Peters, Robbie. 2013. Surabaya, 1945-2010: Neighbourhood, State and Economy in Indonesia's City of Struggle. Singapore: National University of Singapore Press.

Peterson, V. Spike. 2010. "How (The Meaning of) Gender Matters in Political Economy." Dalam International Political Economy: A Reader. Ontario: Oxford University Press, 145-59.

. 1992. "Transgressing Boundaries: Theories of Knowledge, Gender and International Relations." Millenium: Journal of International Studies 21(2):183-306.

Pramono, Mochamad Setyo, Suci Wulansari dan Sutikno. 2012. "Pemetaan Determinan Angka Kematian Bayi di Jawa Timur Berdasarkan Indikator Indeks Pembangunan Kesehatan Masyarakat." Bultin Penelitian Sistem Kesehatan 15(1): 38-46.

Rakhmawati, Farida Nurul. 2015. "Perempuan Madura: "Mengada" di Tengah Himpitan Budaya Matrilokal dan Kekuasaan Patriarkat." Dalam Surokim, peny. Madura: Masyarakat, Budaya, Media, dan Politik. Madura: Puskakom Publik bekerja sama dengan Penerbit Elmatera.

Setiawan, Indra. 2015. "Gubernur Jatim Dorong Peran Perempuan dalam Pembangunan." AntaraJatim.com, 2 Desember. Diakses pada 16 Februari 2017. http://www.antarajatim.com/lihat/berita/168900/gubernur-jatim-dorongperan-perempuan-dalam-pembangunan. 
UNWOMEN. Tanpa tanggal. “The United Nations Fourth World Conference on Women.” $\begin{array}{lllll}\text { Diakses } & \text { pada } & 28 & \text { Juli }\end{array}$ http://www.un.org/womenwatch/daw/beijing/platform/poverty.htm.

Tanpa Nama. 2016a. "Hingga 2016, 50 Daerah Tertinggal Berpotensi Dientaskan.” Direktorat Jenderal Pembangunan Daerah Tertinggal, 6 September. Diakses pada 16 Februari 2017. http://ditjenpdt.kemendesa.go.id/news/read/160906/132hingga-2016--50- daerah-tertinggal-berpotensi-dientaskan.

Tanpa Nama. 2016b. "Pakde Karwo Dukung Pemberdayaan Ekonomi Kaum Perempuan." beritaLima, 11 Oktober. Diakses pada 16 Februari 2017. https://www.beritalima.com/ 2016/10/11/pakde-karwo-dorongpemberdayaan-ekonomi-kaum-perempuan/.

Tickner, J. Ann dan Laura Sjoberg. 2011. Feminism and International Relations: Conversations about the past, present and future. New York: Routledge.

Yesyca, Mita. 2013. “Peningkatan Arus Migrasi TKW-PRT ke PEA.” Dalam Ani Soetjipto, peny. Gender dan Hubungan Internasional: Sebuah Pengantar. Yogyakarta: Jalasutra. 